\title{
Música, pintura y actitud ante la muerte: representaciones musicales en "El Jardín de las Delicias" de EI Bosco y "El triunfo de la muerte" de Brueghel el Viejo
}

Music, painting and attitude towards death: musical performances in "The Garden of Earthly Delights" of El Bosco and "The Triumph of Death" by Brueghel the Elder

Abel Mostaza Prieto

Universidad de Valladolid, España, (abel.mostaza.prieto@hotmail.com)

RESUMEN: La representación de la música (como elemento sonoro) en el plano de la pintura es complicada si no acaso imposible, es por ello que, cuando el pintor decide incluir escenas musicales, pretende idealizar el sonido de la escena o dar algún significado especial a dicha escena musical respecto al conjunto de la obra. Esas instantáneas musicales, por sí mismas, pueden dotar al conjunto general de la obra pictórica de una característica que le es ajena, incluso contraria; es por esto que en los ejemplos propuestos de El Bosco y Brueghel se observa cómo las escenas musicales permiten contrariar el sentido general de las tablas, llegando a contradecir el significado, a priori, que el espectador podría dilucidar.

PALABRAS CLAVE: Música, pintura, muerte, Bosco, Brueghel.

\begin{abstract}
The representation of music (as a sound element) in the plane of painting is complicated, if not impossible. When this happens, painter's intention is include musical scenes pretend to idealize the sound of the scene or give some special meaning to said musical scene. These musical snapshots, by themselves, can give the general set of the pictorial work a characteristic that is alien to it, even contrary; this is why in the proposed examples of El Bosco and Brueghel we observe how the musical scenes allow us to contradict the general sense of the panels, even contradicting the meaning a priori that the viewer could elucidate.
\end{abstract}

KEYWORDS: Music, picture, death, Bosco, Brueghel. 
Representar música es complicado: el plano musical es un plano fugaz que se volatiliza en el mismo instante en el que ha sonado y, sólo si atendemos a la notación musical que desde sus orígenes permitió "escribir" esos sonidos para que otros puedan interpretarlos posteriormente, podremos tener una "idea de sonido" (como grafía) menos efímera pero igualmente exigua (es decir: si somos músicos y nos presentan una partitura podremos tener una idea de cómo suena), pues, sin una interpretación o correspondencia sonora en el instrumento apropiado, sólo será una idea y no será totalmente música en tanto en cuanto no hay sonido correspondiente a esas notas que vemos escritas. El instante sonoro ha sido así plasmado en otras facetas artísticas como la pintura o la escultura, elementos gracias a los cuales nos han llegado testimonios de cómo debieron ser algunos instrumentos del pasado hoy perdidos o en el mejor de los casos en malas condiciones.

Sin embargo, hay algo que esas pinturas comparten con lo representado (y en general podemos decir con todas las artes). Se trata de sensaciones, de lo que la obra provoca en el sujeto. Ruego me perdonen un posible trascendentalismo o simbolismo estético, pero parece ser que la definición de arte mayoritariamente aceptada (y suele ser elemento valorativo incluso en galerías de arte) es aquella que entiende "arte" como sensación, como elemento capaz de emocionar (bien provocando alegría, llanto, dolor, enfado o incluso incertidumbre). ¿Y cuál es el mayor temor que afronta el hombre? ¿Es acaso el que provoca más sensaciones encontradas? Sin duda, para mí la respuesta es clara: la vejez y, a largo plazo, la muerte.

La muerte representa, en sí misma, el destino, la fatalidad, la capacidad trascendental, el dolor e incluso la alegría o la ira. En esta ocasión, y como mero aficionado enamorado del arte en general y de la música en particular, me gustaría relatarles modestamente acerca de dos pinturas al óleo sobre tabla y de la representación que la música tiene ante la muerte en éstas: El jardín de las Delicias de Jheronimus Bosch (el Bosco), y El triunfo de la Muerte de Brueghel el Viejo, ambas tablas de la colección permanente del Museo Nacional del Prado ${ }^{1}$, en Madrid.

\footnotetext{
${ }_{1}^{1}$ Pido al lector que, llegado a este punto y en caso de no conocer los óleos o simplemente si desea visualizarlos, recurra a la página web del Museo Nacional del Prado, donde podrá encontrarlos en alta resolución.
} 


\section{Música y tormento: El jardín de las Delicias de Jheronimus Bosch (el Bosco)}

Según nos informa el propio Museo Nacional del Prado desde su página web (Museo Nacional del Prado, s.f., pp. 1490-1500), se trata de un tríptico portativo² ${ }^{2}$ al óleo sobre madera de roble que pretende representar La Creación Divina (óleo lateral izquierdo), el Paraíso Terrenal de los Sentidos (óleo central) y El Infierno (óleo lateral izquierdo). Bien, mucho se ha hablado ya de este imponente óleo (y yo, personalmente, les recomiendo verlo también cerrado, cuya vista e inscripción no deja indiferente a nadie); pero ahora quiero retomar la idea de este escrito, centrémonos pues en la tabla de la derecha: la representación del Infierno.

Lo primero que visualiza el espectador de El Infierno es la cantidad de monstruos y torturas que el óleo representa, centrándose principalmente en el castigo de los Pecados Capitales y vicios, y donde la mayoría de estas torturas son ejercidas por instrumentos de temática musical (no instrumentos para hacer música como tal, sino también utensilios musicales tales como partituras o incluso unos “oídos siameses" atravesados por una saeta y una navaja que parece separarlos). Por toda esta serie de imágenes, esta sección se ganó el sobrenombre de "El Infierno musical”, lo que nos da una ligera idea del gusto que tenía El Bosco por la música. Son muchos los comentarios y los ríos de tinta que se han vertido en torno a esta obra, aún son más las interpretaciones acerca de lo que pretendía Jheronimus Bosch al asociar la tortura, el Fuego Eterno y el sufrimiento con cuestiones musicales: si criticaba la primacía de la música instrumental (y vocal) frente al entendimiento del texto en la música religiosa, si era una alegoría acerca de la calidad de los instrumentistas de la corte de los Reyes Católicos concretamente de la Capilla de Fernando II de Aragón-, si era un presagio del cariz que estaba tomando la música polifónica profana en las calles del Imperio Español (incluyendo, por supuesto, los Países Bajos), profetizando a todos ellos cuál era el destino de sus libertinas letras y ritmos e incluso una atrevida interpretación que leí recientemente en la que se dice que los instrumentos podrían ser un gozo dionisíaco, según los postulados nietzscheanos, de "ser en uno la divinidad"3 ... Quién sabe el auténtico porqué que llevó a J. Van Aken a pintar esa escena y hacer de este tríptico, junto con gran parte de la obra de este autor, uno de los bienes más preciados del futuro Rey Felipe II.

Lo que es indudable es que, en esta tabla, la música no acaba bien parada y, si atendemos a una pintura similar del mismo autor llamada El Carro de Heno, podemos encontrar precisamente en el

\footnotetext{
${ }^{2}$ Se ha discutido mucho esta cuestión pues, si bien en 1967 Steppe y Gombrich catalogaron el Jardín de las Delicias como una propiedad presente en el castillo Coudenberg de la familia Nassau de Bruselas (Maroto, 2016); por sus grandes dimensiones no parece sensato catalogar dicho tríptico como elemento portátil. 
centro del tríptico y sobre dicho carro que da nombre a la tabla a dos jóvenes músicos de tez pálida a los que no sólo diferentes clases sociales (clero, nobleza y pueblo llano) prestan atención, sino que también fuerzas sobrenaturales y divinas parecen acompañarles en su labor: un ángel parece cantar a la izquierda del espectador respecto a los amantes, un demonio parece tocar un instrumento de viento a la derecha, y el mismísimo Dios se asoma entre la bruma celeste para contemplar la escena. Se produce así un efecto curioso, el Infierno de El Carro de Heno no da ninguna información de qué destino les espera a los músicos de la tabla central y, del mismo modo, en el Jardín de Las Delicias no encontramos ningún músico en la tabla central (aunque sí cierto orden armónico y varios danzantes), pero sí nos anticipa el destino de los músicos.

Concluyamos pues a interpretar el porqué de ese infierno musical, sumamente complejo (más cuando hemos visto que realmente El Bosco sí había pintado escenas donde la música no resultaba mal parada (recordemos El Carro de Heno): mientras la mayoría de nuestro tríptico, El Jardín de las Delicias, transmite una sensación de tranquilidad y bienestar, la región destinada al Infierno capta la atención del espectador porque es el elemento discordante con el resto del tríptico; es allí donde tortura es a música (o quizá sea más propio decir a sonido) lo que Paraíso lo fue a Jardín en la primera tabla. La armonía natural se ve rota precisamente por una de sus mayores aliadas: la música.

\section{Música y consuelo: El triunfo de la muerte de Brueghel el Viejo}

Matías Díaz Padrón, a través de la página web del museo (Padrón, s.f.), nos detalla que se trata de un óleo sobre tabla pintado en torno a 1563 por el pintor flamenco Pieter Brueghel el Viejo, tabla de grandes dimensiones (casi dos metros de largo por metro veinte de alto) en las que se hace una alegoría gráfica de las huestes de la Parca sesgando la vida temerosa de los mortales y pecadores que se resignan o se enfrentan abiertamente a ellas, aun cuando saben que son pocas las esperanzas. Es evidente el terror de la escena como conjunto, pues miremos el individuo que miremos, trate de defenderse, huir o aceptar la muerte; lo hace con pánico, humillación o lástima, el sonido ambiente sería el propio de una batalla, gritos agónicos, llantos y voces, trotar de caballos y ruidos de entrechoque entre espadas.

Sin embargo, hay una escena que se escapa de este aterrador conjunto; una escena en la que el espectador no suele fijarse. En el plano inferior derecho, a ojos del contemplativo, podemos encontrar la única escena en la que un esqueleto no está arrebatando la vida de seres humanos y, a su vez, en la que los seres humanos no parezcan sufrir el mismo, sino que el resto de individuos de la escena: un hombre tañe el laúd y canta, una mujer -que bien podría ser la amante- le hace las funciones de atril, y lo más asombroso, un esqueleto decide acompañarles con un violín. A pesar de la desoladora escena 
en conjunto, estos tres seres no parecen ser conscientes de lo que los rodea, parecen ajenos a la trágica realidad en la que ellos mismos están envueltos (y de la que probablemente acaben formando parte). La escena de los amantes-músicos es capaz de vencer a la Bestia, es la única escena que no se presta asoladora, trágica o acongojante, pues incluso el esqueleto que se une al conjunto parece esbozar una sonrisa amable y alejada de los rostros aterradores del resto de muertos vivientes que desatan su furia.

Así pues, la iconografía musical que se observa en el cuadro aparece diseñada como una estampa aparte, una estampa que aún dentro de la propia batalla narrada por el cuadro nos aleja del terreno de éste (como si se tratase de una obra independiente). Es el triunfo de la vida, del amor y de la música sobre las huestes de la parca.

\section{Conclusiones}

Vemos pues, en sendas obras, la idea de la alegoría paradójica, es decir, una alegoría que para representar su significado recurre precisamente a la carencia de éste o incluso a la antonimia del mismo. En el Jardín de las Delicias, ya desde el mismo nombre, se nos propone la visualización del bíblico vergel como premio de la misma vida. Pero si, como nos propone Javier Sierra ${ }^{4}$ en su libro "El Maestro del Prado" (Sierra, 2013, pp. 207-234), hacemos una lectura occidental, descubriremos que no se trata tanto de una idealización como de una advertencia; El Bosco nos dice "éste es el paraíso que te espera", sí, pero lo hace como premonición para todos aquellos humanos que, como en la tabla central del tríptico, están disfrutando de la vida en bailes, música, comida, y placeres en general. Es decir, los vicios y ocios humanos, por pequeños que sean, te condenan a alojarte en las Calderas de Pedro Botero.

Pero, ¿y en El triunfo de la Muerte? Pues precisamente en esta obra ocurre, al contrario; la alegoría nos haría pensar que nada ni nadie escapa de la muerte, todos estamos sometidos al momento en el que la parca nos saque a bailar la danza macabra que no podemos rechazar. Sin embargo, parece que ella misma cede, aunque sea momentáneamente, ante la música (y me atrevería a aventurar que ante las Artes y toda disciplina humanística en general), pues se une a ser inmortalizada con esos jóvenes amantes. ¿O acaso es menos cierto que aún sigue viva la figura de músicos como Mozart, Juan de la Enzina o Verdi? ¿No han vencido, de alguna manera, ellos a la muerte? Javier Sierra (Sierra, 2013, pp. 235-256) no dista mucho de mi humilde opinión; él argumenta que hay un mensaje velado en el que la vida triunfa ante la muerte, pues, prestando atención a varias escenas de la danza macabra que se

4 No puedo cuanto menos hacer referencia a Sierra como eminente Premio Planeta 2017 con la obra "El fuego invisible". 
representa en el cuadro y viendo que coinciden con el Alfabeto de la Muerte propuesto por Hans Holbein unos años antes de que Brueghel pintase su famosa obra, vemos que hay un comunicado de cuatro letras en la tabla, un anuncio que dice "VITA".

\section{Referencias bibliográficas}

COSSÍO, María José Echarte (2017). "Publicaciones didácticas", Sobre el infierno musical en el "Jardín de las Delicias", no86, pp. 432-435.

MAROTO, Pilar Silva (2016). El Bosco. La Exposición del V Centenario. Museo del Prado: Madrid.

MUSEO NACIONAL DEL PRADO (s.f.). Tríptico del jardín de las delicias.

https://www.museodelprado.es/coleccion/obra-de-arte/triptico-del-jardin-de-lasdelicias/02388242-6d6a-4e9e-a992-e1311 eab3609 (Consulta: 5/11/2017).

PADRÓN, Matías Díaz (s.f). El triunfo de la Muerte [Pieter Bruegel el Viejo]. Página web del Museo Nacional del Prado. https://www.museodelprado.es/aprende/enciclopedia/voz/triunfo-de-lamuerte-el-pieter-bruegel-el-viejo/5a1ea2bf-a269-44be-8466-95e5ae34396e (Consultado: 28/10/2017).

SIERRA, Javier (2013). El Maestro del Prado. Círculo de Lectores: Barcelona. 